\title{
Pengaruh Efikasi Diri, Kecerdasan Emosional, dan Motivasi Belajar Terhadap Prestasi Belajar Matematika Siswa SMA Kelas XI IPA
}

\author{
Aswin ${ }^{1, \text { a) }}$, Djadir $^{1}$, dan Rusli ${ }^{1}$ \\ ${ }^{1}$ Jurusan Matematika FMIPA Universitas Negeri Makassar \\ a) aswinsalsri23@gmail.com
}

\begin{abstract}
Abstrak. Penelitian ini dilakukan untuk mengetahui pengaruh efikasi diri, kecerdasan emosional, dan motivasi terhadap prestasi belajar siswa kelas XI IPA SMA di Makassar. Penelitian ini adalah penelitian ex-post facto yang bersifat kausalitas dengan sampel penelitian sebanyak 132 siswa dari kelas XI IPA SMA di Makassar yang dipilih dengan menggunakan random sampling. Teknik pengumpulan data menggunakan instrumen: (1) angket efikasi diri, (2) angket kecerdasan emosional, (3) angket motivasi belajar, dan (4) tes prestasi belajar matematika. Data dianalisis dengan statistik deskriptif dan statistik inferensial dengan analisis jalur. Hasil penelitian menunjukkan bahwa: (1) efikasi diri siswa berada pada kategori tinggi, (2) kecerdasan emosional siswa berada pada kategori tinggi, (3) motivasi belajar siswa berada pada kategori tinggi, (4) prestasi belajar matematika siswa berada pada kategori sedang, (5) efikasi diri berpengaruh positif terhadap prestasi belajar matematika siswa, (6) kecerdasan emosional berpengaruh positif terhadap prestasi belajar matematika siswa, (7) ) motivasi belajar berpengaruh positif terhadap prestasi belajar matematika siswa, (8) efikasi diri berpengaruh secara tidak langsung terhadap prestasi belajar matematika siswa melalui variabel motivasi belajar, (9) kecerdasan emosional berpengaruh secara tidak langsung terhadap prestasi belajar matematika siswa melalui variabel motivasi belajar.
\end{abstract}

Kata Kunci: Efikasi diri, Kecerdasan emosional, Motivasi belajar, Prestasi Belajar Matematika siswa.

\begin{abstract}
This study was conducted to determine effect of self efficacy, emotional intelegence, and learning motivation on Student's mathematics Learning achievement of grade XI IPA of SMA at Makassar. This research is ex post facto research which is causality with research sample counted 132 students from class XI IPA SMA at Makassar selected by using random sampling. Technique of collecting data using instrument: (1) questionnaire of self efficacy, (2) questionnaire of emotional intelegence, (3) questionnaire of learning motivation, and (4) test result of mathematics learning. Data were analyzed with descriptive statistics and inferential statistics with path analysis. The result of the research shows that: (1) the student's self efficacy is in the high category, (2) the student's emotional intelegence is in the high category, (3) the student's learning motivation is in the high category, (4) student's mathematics learning achievement in the medium category, (5) student's self efficacy directly effect on student's mathematics learning achievement, (6) student's emotional intelegence directly effect on student's mathematics learning achievement, (7) student's learning motivation directly effect student's mathematics learning achievement, (8) student's self efficacy indirectly effect on student's mathematics learning achievement through variable learning motivation, (9) student's emotional intelegence indirectly effect on student's mathematics learning achievement through variable learning motivation.

Keywords: Self efficacy, Emotional intelegence, Learning motivation, Student's mathematics learning achievement.
\end{abstract}




\section{PENDAHULUAN}

Faktor- faktor yang mempengaruhi prestasi belajar matematika siswa terdiri atas dua faktor yaitu faktor internal dan faktor eksternal. Faktor internal adalah faktor yang asalnya dari dalam diri seseorang atau individu itu sendiri. Faktor internal biasanya berupa sikap juga sifat yang melekat pada diri seseorang. Faktor internal yang terdapat dalam diri siswa yang berpengaruh terhadap prestasi belajar adalah efikasi diri, kecerdasan emosional, motivasi belajar dan minat belajar. Sedangkan, faktor eksternal adalah faktor yang asalnya dari luar diri seseorang atau individu. Faktor eksternal yang berpengaruh terhadap prestasi belajar siswa adalah keadaan keluarga, keaadan sekolah dan keadaan masyarakat.

Salah satu faktor internal yang mempengaruhi prestasi belajar adalah efikasi diri. Bandura (1994) mengatakan bahwa efikasi diri pada dasarnya adalah hasil dari proses kognitif berupa keputusan, keyakinan, atau pengharapan tentang sejauh mana individu memperkirakan kemampuan dirinya dalam melaksanakan tugas atau tindakan tertentu yang diperlu-kan untuk mencapai hasil yang diingin-kan. Menurutnya, efikasi diri tidak berkaitan dengan kecakapan yang dimiliki melainkan berkaitan dengan keyakinan individu mengenai hal yang dapat dilakukan dengan kecakapan yang individu miliki seberapapun besarnya. Sedangkan menurut Hidayat (2016) efikasi diri adalah keyakinan seseorang memperkirakan kemampuan dirinya dalam mengerjakan tugas, aktivitas ataupun usaha untuk mencapai tujuan yang ia inginkan dalam situasi-situasi tertentu. Menurutnya, efikasi diri dapat menumbuhkan keyakinan untuk berhasil dalam penyelesaian tugas.

Siswa yang memiliki efikasi diri yang tinggi maka akan memiliki prestasi matematika yang baik di karenakan memiliki ketajaman perhitungan matematika. Namun, siswa yang memiliki efikasi diri yang rendah maka akan memiliki tingkat ketajaman perhitungan yang rendah sehingga akan berpengaruh terhadap prestasi belajarnya. Hal ini sejalan dengan penelitian yang dilakukan oleh Muklis dan Sanhadi (2016) yang menyatakan bahwa Efikasi diri berpengaruh secara positif dengan prestasi akademis siswa.

Selain efikasi diri, faktor internal yang berpengaruh terhadap prestasi belajar adalah kecerdasan emosional. Menurut Setyawan dan Simbolon (2018) kecerdasan emosional merupakan kemampuan merasakan, memahami dan secara selektif menerapkan daya dan kepekaan emosi sebagai sumber energi dan pengaruh yang manusiawi dari seorang siswa di mana dengan adanya kecerdasan emosional yang tinggi dari siswa maka dapat menuntut siswa untuk mengakui, menghargai perasaan pada diri sendiri dan orang lain serta menanggapinya dengan tepat, menerapkan secara efektif energi emosi dalam kehidupan sehari-hari terutama dalam sekolahnya. Sedangkan, menurut Gusniawati (2015) kecerdasan emosional adalah kemampuan seseorang dalam mengendalikan emosinya secara cerdas berdasarkan indicator-indikator kecerdasan emosional seperti: mengenali emosi diri, mengelola dan mengontrol emosi, memotivasi diri, mengenali emosi orang lain (empati), kemampuan untuk membina hubungan (kerjasama) dengan orang lain, serta memahami dan mengontrol emosi diri sendiri dan orang lain secara akurat, sehingga dapat menggunakan emosi dengan baik dan mengelolanya menjadi sebuah kecerdasan yang berguna untuk hal-hal yang positif.

Kecerdasan emosional adalah kemampuan sesorang untuk mengerti emosi diri sendiri dan orang lain, dan menggunakan perasaan tersebut untuk memadukan pikiran dan tindakan. Siswa yang memiliki kecerdasan emosional yang baik maka akan berpengaruh terhadap prestasi belajarnya. Hal ini sejalan dengan penelitian yang dilakukan oleh Alfiah, Opod dan Sinolungan (2017) yang menyatakan bahwa antara kecerdasan emosional dan prestasi memiliki hubungan.

Selain efikasi diri dan kecerdasan emosional faktor internal yang berpengaruh terhadap prestasi belajar adalah motivasi belajar. Menurut Haling (2017), motivasi belajar adalah daya penggerak dalam diri siswa untuk belajar. Kemudian dilanjutkan, motivasi adalah daya penggerak yang menjadi aktif, motivasi menjadi aktif pada saat tertentu terutama bila kebutuhan untuk mencapai tujuan dapat dirasakan. Sedangkan menurut Mulyaningsih (2014), motivasi belajar yaitu suatu 
dorongan atau kemauan seseorang untuk melakukan aktivitas belajar agar prestasi belajar dapat dicapai secara optimal.

Motivasi belajar adalah daya penggerak bagi sesorang individu untuk belajar. Siswa yang memiliki motivasi belajar yang baik maka akan memiliki prestasi belajar yang baik, hal ini sejalan dengan penelitian yang dilakukan oleh Cleopatra(2015) yang menyatakan memperoleh bahwa variabel motivasi belajar berpengaruh secara signifikan terhadap prestasi belajar siswa, selain itu variabel motivasi mempunyai kontribusi sangat besar, yang secara efektif besar sumbangan terhadap prestasi belajar yaitu sebesar $93,1 \%$.

Faktor internal yang ada pada diri siswa yaitu efikasi diri, kecerdasan emosional, dan motivasi belajar yang menunjang prestasi belajar, maka perlu diperhatikan pengaruh efikasi diri siswa teradap prestasi belajar matematika siswa, pengaruh kecerdasan emosional terhadap prestasi belajar matematika siswa, pengaruh motivasi belajar terhadap prestasi belajar matematika siswa. Penelitian ini bertujuan untuk mengetahui pengaruh efikasi diri, kecerdasan emosional dan motivasi belajar terhadap prestasi belajar.

\section{METODE PENELITIAN}

Jenis penelitian yang digunakan adalah penelitian kuantitatif dengan pendekatan Ex post facto. Penelitian ini dilaksanakan di salah satu SMA di Makassar. Pengambilan sampel pada penelitian ini menggunakan teknik random sampling yaitu mengambil empat kelas secara acak. Populasi dalam penelitian ini adalah siswa kelas XI IPA disalah satu SMA di Makassar. Adapun banyak sampel dalam penelitian ini adala 132 siswa. Instrument yang digunakan dalam penelitian ini yaitu tes prestasi belajar matematika, kuisioner untuk mengukur efikasi diri, kecerdasan emosional, dan motivasi belajar. Variabel yang diselidiki dalam penelitian ini yaitu Efikasi diri, Kecerdasan emosional, Motivasi Belajar dan Prestasi belajar matematika.

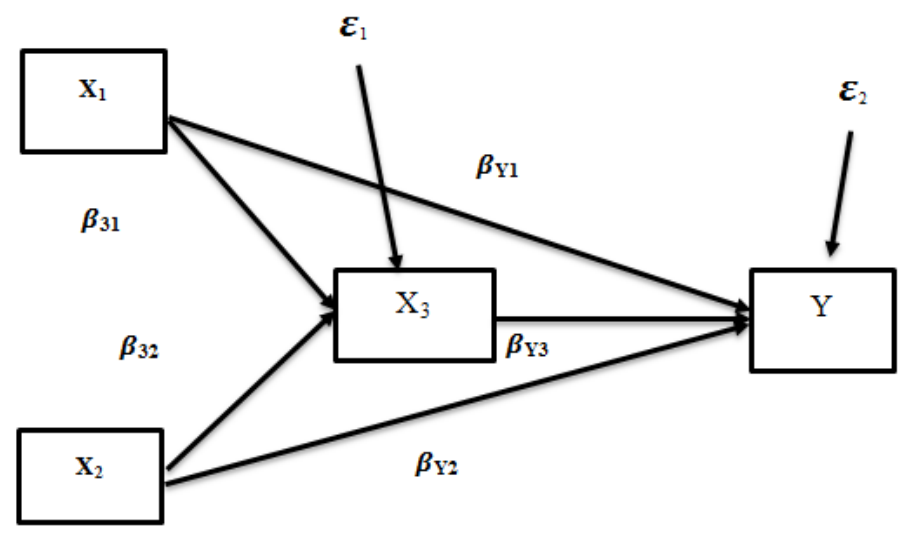

GAMBAR 1. Desain Penelitian

Keterangan :

$\mathrm{X}_{1} \quad=$ Efikasi diri

$\mathrm{X}_{2} \quad=$ Kecerdasan emosional

$\mathrm{X}_{3} \quad=$ Motivasi belajar

$\mathrm{Y} \quad=$ Prestasi belajar Matematika

$\varepsilon_{1} \quad=$ error/variabel residu 1

$\varepsilon_{2} \quad=$ error/variabel residu 2

$\beta_{31} \quad=$ koefisien jalur $X_{1}$ terhadap $X_{3}$ 
$\beta_{32} \quad=$ koefisien jalur $X_{2}$ terhadap $X_{3}$

$\beta_{\mathrm{y} 1} \quad=$ koefisien jalur $\mathrm{X}_{1}$ terhadap $\mathrm{Y}$

$\beta_{\mathrm{y} 2} \quad=$ koefisien jalur $\mathrm{X}_{2}$ terhadap $\mathrm{Y}$

$\beta_{\mathrm{y} 3} \quad=$ koefisien jalur $\mathrm{X}_{3}$ terhadap $\mathrm{Y}$

Berdasarkan diagram jalur pada Gambar 1. dapat dituliskan model persamaan strukturalnya sebagai berikut:

$X_{3}=\beta_{31} X_{1}+\beta_{32} X_{2}++\varepsilon_{1}$

$Y=\beta_{\mathrm{y} 1} X_{1}+\beta_{\mathrm{y} 2} X_{2}+\beta_{\mathrm{y} 3} \mathrm{X}_{3}+\beta_{\mathrm{y} 3} \mathrm{X}_{3}\left(\beta_{31} \mathrm{X}_{1}+\beta_{32} \mathrm{X}_{2}\right)++\varepsilon_{2}$

Data yang telah terkumpul kemudian diolah dengan menggunakan teknik analisis statistik, yaitu analisis statistik deskriptif dan analisis statistik inferensial. Analisis statistik deskriptif digunakan untuk mendeskripsikan karakteristik skor responden penelitian untuk masing-masing variabel meliputi mean, median, variansi, minumum, maksimum, dan kategorisasi. Analisis statistik inferensial digunakan untuk menguji hipotesis penelitian. Dalam penelitian ini digunakan path analysis (analisis jalur), yaitu bukan hanya untuk mengetahui apakah suatu variabel eksogen berpengaruh ke variabel endogen, melainkan juga untuk mengetahui besarnya pengaruh langsung dan tidak langsung

\section{HASIL DAN PEMBAHASAN}

\section{Hasil Analisis Statistika Deskriptif}

Prestasi Belajar

TABEL 1. Statistik Skor Prestasi Belajar Matematika

\begin{tabular}{cc}
\hline Statistik & Nilai Statistik \\
\hline Ukuran Sampel $(\mathrm{n})$ & 132 \\
Skor tertinggi $\left(\mathrm{X}_{\text {maks }}\right)$ & 92 \\
Skor terendah $\left(\mathrm{X}_{\text {min }}\right)$ & 44 \\
Skor rata-rata $(\bar{x})$ & 71,12 \\
Standar deviasi $(\mathrm{s})$ & 8,996 \\
Variansi $\left(\mathrm{s}^{2}\right)$ & 80,932
\end{tabular}

Tabel 1 menggambarkan bahwa dari sejumlah sampel yang ada yaitu 132 siswa, rata-rata skor prestasi belajar matematika siswa adalah sebesar 71,12 dari skor ideal 100. Terlihat pula bahwa standar deviasi sebesar 8,996 artinya skor prestasi belajar siswa penyebaran data tidak terlalu besar artinya data hanya berada disekitar nilai rata-rata.

TABEL 2. Distribusi Frekuensi dan Persentase Skor Prestasi Belajar Matematika

\begin{tabular}{cccc}
\hline Interval Nilai & Kategori & Frekuensi & $\begin{array}{c}\text { Persentase } \\
(\boldsymbol{\%})\end{array}$ \\
\hline skor $<40$ & Sangat Rendah & 0 & $0 \%$ \\
$40 \leq$ skor $<55$ & Rendah & 3 & $2,27 \%$ \\
$55 \leq$ skor $<75$ & Sedang & 82 & $62,12 \%$ \\
$75 \leq$ skor $<85$ & Tinggi & 42 & $31,82 \%$ \\
$85 \leq$ skor $<100 \quad$ Sangat Tinggi & 5 & $3,79 \%$ \\
Jumlah & & 132 & 100 \\
\hline
\end{tabular}

(Jamil, 2015)

Tabel 2 menggambarkan bahwa skor prestasi belajar siswa tergolong ketegori sedang dengan presentasi yang cukup besar yaitu $62,12 \%$. Terlihat pula bahwa siswa yang memiliki katergori 
prestasi yang sangat rendah yaitu sebesar $0 \%$ artinya tidak terdapat siswa yang tergolong prestasi sangat rendah.

\section{Efikasi Diri}

TABEL 3. Statistik Skor Efikasi Diri

\begin{tabular}{cc}
\hline Statistik & Nilai Statistik \\
\hline Ukuran Sampel $(\mathrm{n})$ & 132 \\
Skor tertinggi $\left(\mathrm{X}_{\text {maks }}\right)$ & 135,084 \\
Skor terendah $\left(\mathrm{X}_{\min }\right)$ & 58,949 \\
Skor rata-rata $(\bar{x})$ & 95,6183 \\
Standar deviasi $(\mathrm{s})$ & 14,509827 \\
Variansi $\left(\mathrm{s}^{2}\right)$ & 210,535 \\
\hline
\end{tabular}

Tabel 3 memperlihatkan bahwa dari sejumlah sampel yang ada yaitu 132 siswa, rata-rata skor efikasi diri siswa adalah sebesar 95,6183 dari skor ideal 135,703. Terlihat pula bahwa standar deviasi sebesar 14,50 artinya skor efikasi diri siswa penyebaran data tidak terlalu besar artinya data hanya berada disekitar nilai rata-rata.

TABEL 4. Distribusi Frekuensi dan Persentase Skor Efikasi Diri

\begin{tabular}{cccc}
\hline Interval Nilai & Kategori & Frekuensi & $\begin{array}{c}\text { Persentase } \\
(\mathbf{\%})\end{array}$ \\
\hline $27,000 \leq$ skor $<46,394$ & Sangat Rendah & 0 & $0 \%$ \\
$46,394 \leq$ skor $<85,838$ & Rendah & 33 & $25 \%$ \\
$85,838 \leq$ skor $<120,796$ & Tinggi & 94 & $71,21 \%$ \\
$120,796 \leq$ skor $<135,703$ & Sangat Tinggi & 5 & $3,79 \%$ \\
Jumlah & & 132 & 100 \\
\hline
\end{tabular}

Tabel 4 memperlihatkan bahwa skor efikasi diri siswa tergolong ketegori tinggi dengan presentasi yang cukup besar yaitu $71,21 \%$. Terlihat pula bahwa siswa yang memiliki katergori efikasi diri yang sangat rendah yaitu sebesar $0 \%$ artinya tidak terdapat siswa yang tergolong efikasi diri sangat rendah.

\section{Kecerdasan Emosional}

TABEL 5. Statistik Skor Kecerdasan Emosional

\begin{tabular}{cc}
\hline Statistik & Nilai Statistik \\
\hline Ukuran Sampel $(\mathrm{n})$ & 132 \\
Skor tertinggi $\left(\mathrm{X}_{\text {maks }}\right)$ & 158,533 \\
Skor terendah $\left(\mathrm{X}_{\text {min }}\right)$ & 78,303 \\
Skor rata-rata $(\bar{x})$ & 125,24107 \\
Standar deviasi $(\mathrm{s})$ & 12,870831 \\
Variansi $\left(\mathrm{s}^{2}\right)$ & 165,658 \\
\hline
\end{tabular}

TABEL 6. Distribusi Frekuensi dan Persentase Skor Kecerdasan Emosional

\begin{tabular}{cccc}
\hline Interval Nilai & Kategori & Frekuensi & Persentase (\%) \\
\hline $32,000 \leq$ skor $<52,422$ & Sangat Rendah & 0 & $0 \%$ \\
$52,422 \leq$ skor $<96,450$ & Rendah & 2 & $1,52 \%$ \\
$96,450 \leq$ skor $<146,699$ & Tinggi & 127 & $96,21 \%$ \\
$146,699 \leq$ skor $<173,343$ & Sangat Tinggi & 3 & $2,27 \%$ \\
Jumlah & & 132 & 100 \\
\hline
\end{tabular}

Tabel 5 menggambarkan bahwa dari sejumlah sampel yang ada yaitu 132 siswa, rata-rata skor kecerdasan emosional siswa adalah sebesar 125, 241 dari skor ideal 173,343. Terlihat pula 
bahwa standar deviasi sebesar 12,87 artinya skor kecerdasan emosional penyebaran data tidak terlalu besar artinya data hanya berada disekitar nilai rata-rata.

Tabel 6 menggambarkan bahwa kecerdasan emosional siswa tergolong ketegori tinggi dengan presentasi yang sangat besar yaitu 96,21\%. Terlihat pula bahwa siswa yang memiliki katergori kecerdasan emosional yang sangat rendah yaitu sebesar $0 \%$ artinya tidak terdapat siswa yang tergolong kecerdasan emosional sangat rendah.

\section{Motivasi Belajar}

TABEL 7. Statistik Skor Motivasi Belajar

\begin{tabular}{cc}
\hline Statistik & Nilai Statistik \\
\hline Ukuran Sampel $(\mathrm{n})$ & 132 \\
Skor tertinggi $\left(\mathrm{X}_{\text {maks }}\right)$ & 89,440 \\
Skor terendah $\left(\mathrm{X}_{\text {min }}\right)$ & 35,522 \\
Skor rata-rata $(\bar{x})$ & 63,90458 \\
Standar deviasi $(\mathrm{s})$ & 9,769818 \\
Variansi $\left(\mathrm{s}^{2}\right)$ & 95,449 \\
\hline
\end{tabular}

Tabel 7 memperlihatkan bahwa dari sejumlah sampel yang ada yaitu 132 siswa, rata-rata skor motivasi belajar siswa adalah sebesar 63,90 dari skor ideal 94,347. Terlihat pula bahwa standar deviasi sebesar 9,769 artinya skor motivasi belajar penyebaran data tidak terlalu besar artinya data hanya berada disekitar nilai rata-rata.

TABEL 8. Distribusi Frekuensi dan Persentase Skor Motivasi Belajar

\begin{tabular}{rccc}
\hline Interval Nilai & Kategori & Frekuensi & $\begin{array}{c}\text { Persentase } \\
(\boldsymbol{\%})\end{array}$ \\
\hline $14,000 \leq$ skor $<26,020$ & Sangat Rendah & 0 & $0 \%$ \\
$26,020 \leq$ skor $<51,930$ & Rendah & 15 & $11,37 \%$ \\
$51,930 \leq$ skor $<80,084$ & Tinggi & 110 & $83,33 \%$ \\
$80,084 \leq$ skor $<94,347$ & Sangat Tinggi & 7 & $5,30 \%$ \\
Jumlah & & 132 & 100 \\
\hline
\end{tabular}

Tabel 8 memperlihatkan bahwa motivasi belajar siswa tergolong ketegori tinggi dengan presentasi yang sangat besar yaitu $83,33 \%$. Terlihat pula bahwa siswa yang memiliki katergori motivasi belajar yang sangat rendah yaitu sebesar $0 \%$ artinya tidak terdapat siswa yang tergolong motivasi belajar sangat rendah.

\section{Hasil Analisis Statistik Inferensial}

Uji Prasyarat

a. Uji Multikolinearitas

TABEL 9. Hasil Uji Multikoleniaritas

\begin{tabular}{ccccc}
\hline Model & Variabel & Tolarance & VIF & Keterangan \\
\hline 1 & Efikasi Diri & 0,740 & 1,352 & Tidak terjadi multikoleniaritas \\
& Kecerdasan Emosional & 0,740 & 1,352 & Tidak terjadi multikoleniaritas \\
2 & Efikasi Diri & 0,482 & 2,076 & Tidak terjadi multikoleniaritas \\
& Kecerdasan Emosional & 0,653 & 1,532 & Tidak terjadi multikoleniaritas \\
& Motivasi Belajar & 0,440 & 2,273 & Tidak terjadi multikoleniaritas \\
\hline
\end{tabular}

Tabel 9 menggambarkan bahwa nilai Tolerance setiap variabel lebih besar dari 0,1 dan nilai VIF setiap varibel untuk setiap model lebih kecil dari 10, sehingga antar variabel bebas tidak terjadi gejala multikolinearitas 
b. Uji Autokorelasi

TABEL 10. Hasil Uji Autokorelasi

\begin{tabular}{cll}
\hline Model & \multicolumn{1}{c}{ Variabel } & DW \\
\hline 1 & Efikasi Diri & 2,291 \\
& Kecerdasan Emosional & 1,687 \\
2 & $\begin{array}{l}\text { Efikasi Diri } \\
\text { Kecerdasan Emosional } \\
\text { Motivasi Belajar }\end{array}$ & \\
\hline
\end{tabular}

Tabel 10 memperlihatkan bahwa antara efikasi diri dan kecerdasan emosional terhadap motivasi belajar matematika diperoleh nilai $\mathrm{DW}=2,291$. Pada taraf signifikan $5 \%$ jumlah sampel 132, jumlah variabel independen adalah 2 , variabel dependen adalah 1 maka nilai $\mathrm{dL}=$ 1,6696 dan dU=1,7624. Sehingga diperoleh DW berada pada du $<$ DW $<4-$ du yaitu 1,6696 < $2,291<2,3304$. Jadi, tidak ada autokorelasi positif maupun negatif pada variabel efikasi diri, kecerdasan emosional dan motivasi belajar

Sedangkan hasil uji autokorelasi antara efikasi diri, kecerdasan emosional dan motivasi belajar terhadap prestasi belajar matematika diperoleh nilai DW $=1,687$. Pada taraf signifikan $5 \%$ jumlah sampel 132, jumlah variabel independent adalah 3, variabel dependen adalah 1 maka nilai $\mathrm{dL}=1,6539$ dan $\mathrm{dU}=1,7786$. Sehingga diperoleh $\mathrm{DW}$ berada pada $\mathrm{du}<\mathrm{DW}<4-$ du yaitu $1,6539<1,687<2,3461$. Jadi, tidak ada autokorelasi positif maupun negatif pada variabel efikasi diri, kecerdasan emosional, motivasi belajar dan prestasi belajar.

c. Uji Heterokedasitas

TABEL 11. Hasil Uji Heteroskedastisitas

\begin{tabular}{cccc}
\hline Model & Variabel & Signifikansi & Keterangan \\
\hline 1 & Efikasi Diri & 0,085 & Tidak terjadi \\
& Kecerdasan Emosional & 0,381 & heteroskedastisitas \\
2 & Efikasi Diri & 0,860 & Tidak terjadi \\
& Kecerdasan Emosional & 0,637 & heteroskedastisitas \\
& Motivasi Belajar & 0,418 & \\
\hline
\end{tabular}

Tabel 11 menggambarkan bahwa model 1 dan model 2 diperoleh nilai sig $>0,05$. Berarti tidak ada satupun variabel independent yang signifikan secara statistik mempengaruhi variabel dependent. Jadi, dapat disimpulkan bahwa model regresi tidak mengandung adanya heteroskedastisitas.

Pengujian Hipotesis

TABEL 12. Hasil Uji Substruktural Kedua

\begin{tabular}{ccccccc}
\hline $\begin{array}{c}\text { Variabel } \\
\text { Independen }\end{array}$ & $\begin{array}{c}\text { Standarized } \\
\text { Coefficient } \\
\text { beta }\end{array}$ & $\mathbf{T}$ & $\begin{array}{c}\text { Sig. } \\
\text { Coefficient }\end{array}$ & $\boldsymbol{R}^{\mathbf{2}}$ & $\boldsymbol{F}$ & Sig. Anova \\
\hline $\mathbf{X}_{\mathbf{1}}$ & 0,207 & 2,216 & 0,035 & 0,415 & 30,260 & 0,000 \\
$\mathbf{X}_{\mathbf{2}}$ & 0,242 & 2,892 & 0,005 & & & \\
$\mathbf{X}_{\mathbf{3}}$ & 0,301 & 2,957 & 0,004 & & & \\
\hline
\end{tabular}

\section{a. Pengujian hipotesis 1}

Efikasi diri berpengaruh secara positif terhadap Prestasi belajar matematika siswa $\mathrm{H}_{0}: \beta_{\mathrm{Y} 1}=0$ lawan $\mathrm{H}_{1}: \beta_{\mathrm{Y} 1}>0$

Tabel 12 memperlihatkan nilai signifikansi $X_{1}$ adalah sebesar 0,035. Pada hipotesis $I$ menggunakan uji satu pihak yaitu pihak kanan maka nilai signifikansi $\mathrm{X}_{1}$ berubah menjadi 
0,0175. Sehingga, nilai signifikansi dari $\mathrm{X}_{1}$ lebih kecil dari 0,05 yang artinya $\mathrm{H}_{0}$ di tolak. Dengan demikian, variabel efikasi diri berpengaruh positif yang signifikan terhadap prestasi belajar.

\section{b. Pengujian hipotesis 2}

Kecerdasan emosional berpengaruh secara positif terhadap Prestasi belajar matematika siswa $\mathrm{H}_{0}: \beta_{\mathrm{Y} 2}=0$ lawan $\mathrm{H}_{1}: \beta_{\mathrm{Y} 2}>0$

Tabel 12 memperlihatkan nilai signifikansi $X_{2}$ adalah sebesar 0,005. Pada hipotesis 2 menggunakan uji satu pihak yaitu pihak kanan maka nilai signifikansi $\mathrm{X}_{2}$ berubah menjadi 0,0025. Sehingga, nilai signifikansi dari $\mathrm{X}_{2}$ lebih kecil dari 0,05 yang artinya $\mathrm{H}_{0}$ di tolak. Dengan demikian, variabel kecerdasan emosional berpengaruh positif yang signifikan terhadap prestasi belajar.

\section{c. Pengujian hipotesis 3}

Motivasi belajar berpengaruh secara positif terhadap Prestasi belajar matematika siswa

$\mathrm{H}_{0}: \beta_{\mathrm{Y} 3}=0$ lawan $\mathrm{H}_{1}: \beta_{\mathrm{Y} 3}>0$

Tabel 12 memperlihatkan nilai signifikansi $\mathrm{X}_{3}$ adalah sebesar 0,004. Pada hipotesis 3 menggunakan uji satu pihak yaitu pihak kanan maka nilai signifikansi $X_{3}$ berubah menjadi 0,002. Sehingga, nilai signifikansi dari $\mathrm{X}_{3}$ lebih kecil dari 0,05 yang artinya $\mathrm{H}_{0}$ di tolak. Dengan demikian, variabel motivasi belajar berpengaruh positif yang signifikan terhadap prestasi belajar.

TABEL 13. Hasil Uji Substruktural Pertama

\begin{tabular}{ccccccc}
\hline $\begin{array}{c}\text { Variabel } \\
\text { Independen }\end{array}$ & $\begin{array}{c}\text { Standarized } \\
\text { Coefficient } \\
\text { beta }\end{array}$ & $\mathbf{T}$ & $\begin{array}{c}\text { Sig. } \\
\text { Coefficient }\end{array}$ & $\boldsymbol{R}^{\mathbf{2}}$ & $\boldsymbol{F}$ & $\begin{array}{c}\text { Sig. } \\
\text { Anova }\end{array}$ \\
\hline $\mathbf{X}_{\mathbf{1}}$ & 0,564 & 8,309 & 0,000 & 0,560 & 82,088 & 0,000 \\
$\mathbf{X}_{\mathbf{2}}$ & 0,282 & 4,149 & 0,000 & & & \\
\hline
\end{tabular}

\section{d. Pengujian hipotesis 4}

Efikasi diri berpengaruh terhadap Prestasi belajar matematika melalui variabel motivasi belajar siswa

$\mathrm{H}_{0}: \beta_{31} \times \beta_{\mathrm{Y} 3}=0$ lawan $\mathrm{H}_{1}: \beta_{31} \times \beta_{\mathrm{Y} 3}>0$

Tabel 13 memperlihatkan nilai signifikansi $X_{1}$ adalah sebesar 0,000. Sehingga varibel $X_{1}$ berpengaruh secara signifikan terhadap $\mathrm{X}_{3}$ karena nilai signifikansi dari $\mathrm{X}_{1}$ lebih kecil dari 0,05 . Pada hipotesis 3 diperoleh variabel motivasi belajar berpengaruh positif yang signifikan terhadap prestasi belajar. Oleh karena itu, pada hipotesis $4 \mathrm{H}_{0}$ ditolak. Dengan demikian variabel efikasi diri berpengaruh terhadap prestasi belajar melalui variabel motivasi belajar siswa.

\section{e. Pengujian hipotesis 5}

Efikasi diri berpengaruh terhadap Prestasi belajar matematika melalui variabel motivasi belajar siswa

$\mathrm{H}_{0}: \beta_{32} \times \beta_{\mathrm{Y} 3}=0$ lawan $\mathrm{H}_{1}: \beta_{32} \times \beta_{\mathrm{Y} 3}>0$

Tabel 13 memperlihatkan nilai signifikansi $X_{2}$ adalah sebesar 0,000. Sehingga varibel $X_{2}$ berpengaruh secara signifikan terhadap $\mathrm{X}_{3}$ karena nilai signifikansi dari $\mathrm{X}_{2}$ lebih kecil dari 0,05 . Pada hipotesis 3 diperoleh variabel motivasi belajar berpengaruh positif yang signifikan terhadap prestasi belajar. Oleh karena itu, pada hipotesis $5 \mathrm{H}_{0}$ ditolak. Dengan demikian 
variabel kecerdasan emosional berpengaruh terhadap prestasi belajar melalui variabel motivasi belajar siswa.

\section{Pembahasan}

\section{Pembahasan Substruktur 1}

Persamaan regresi linear $X_{1}$ atas $X_{2}$ dan $X_{3}$ yang diperoleh dari perhitungan pada Tabel 13 adalah $X_{3}=0,564 X_{1}+0,282 X_{2}$. Persamaan regresi $X_{1}$ atas $X_{2}$ dan $X_{3}$ tersebut menunjukkan bahwa setiap kenaikan satu unit $X_{1}$ akan menaikkan $X_{3}$ sebesar 0,564 . Selanjutnya untuk setiap kenaikan satu unit $\mathrm{X}_{2}$ akan menaikkan $\mathrm{X}_{3}$ sebesar 0,282.

Berdasarkan hasil analisis regresi pada substruktur I, diketahui bahwa kedua variabel eksogen (efikasi diri dan kecerdasan emosional) secara simultan berpengaruh signifikan terhadap motivasi belajar siswa, yaitu sebesar $56 \%\left(\mathrm{R}^{2}=0,56\right)$, sedangkan sisanya dipengaruhi oleh variabel lain di luar model. Dengan demikian motivasi belajar dapat diprediksi oleh efikasi diri dan kecerdasan emosional.

Berdasarkan hasil analisis regresi secara parsial pada substruktur I, terdapat pengaruh langsung positif efikasi diri terhadap motivasi belajar dan pengaruh langsung positif kecerdasan emosional terhadap motivasi belajar. Efikasi diri siswa yang tinggi maka akan diikuti dengan motivasi siswa yang tinggi pula. Sementara itu, kecerdasan emosional juga ikut berpengaruh terhadap motivasi belajar siswa. Siswa yang memiliki tingkat kecerdasan emosional yang tinggi maka akan memiliki motivasi belajar yang baik.

\section{Pembahasan Substruktur 2}

Persamaan regresi linear $\mathrm{Y}$ atas $\mathrm{X}_{1}, \mathrm{X}_{2}$, dan $\mathrm{X}_{3}$ yang di peroleh dari perhitungan pada Tabel 12 adalah $Y=0,207 X_{1}+0,242 X_{2}+0,301 X_{3}+0,301 X_{3}\left(0,207 X_{1}+0,242 X_{2}\right)$. Persamaan regresi $Y$ atas $X_{1}, X_{2}$, dan $X_{3}$ tersebut menunjukkan bahwa setiap kenaikan satu unit $X_{1}$ akan menaikkan $\mathrm{Y}$ sebesar 0,207. Selanjutnya untuk setiap kenaikkan satu unit $\mathrm{X}_{2}$ akan menaikkan $\mathrm{Y}$ sebesar 0,242 . Kemudian untuk setiap kenaikkan satu unit $X_{3}$ akan menaikkan $Y$ sebesar 0,301. Selain itu, untuk setiap kenaikan satu unit $\mathrm{X}_{3} \mathrm{X}_{1}$ (pengaruh tidak langsung) akan meanikkan $\mathrm{Y}$ sebesar 0,169 dan setiap kenaikan $\mathrm{X}_{3} \mathrm{X}_{2}$ (pengaruh tidak langsung) akan menaikkan $\mathrm{Y}$ sebesar 0,085. Kemudian berdasarkan hasil analisis regresi substruktur kedua, diketahui bahwa efikasi diri, kecerdasan emosional, dan motivasi belajar secara bersama-sama memberi pengaruh yang signifikan terhadap prestasi belajar matematika siswa sebesar $41,5 \%(R 2=0,415)$ sedangkan sisanya dipengaruhi oleh variabel lain diluar model.

\section{KESIMPULAN}

Efikasi diri, kecerdasan emosional dan motivasi belajar berpengaruh secara positif terhadap prestasi belajar matematika siswa. Siswa yang memiliki efikasi diri, kecerdasan emosional dan motivasi belajar yang tinggi maka akan memiliki prestasi belajar matematika yang baik, begitupun begitupun dengan siswa yang memiliki efikasi diri yang rendah maka akan memiliki tingkat prestasi belajar yang kurang baik

Efikasi diri dan kecerdasan emosional berpengaruh secara positif terhadap prestasi belajar matematika siswa melalui variabel motivasi belajar. Siswa yang memiliki tingkat efikasi diri dan kecerdasan emosional yang tinggi maka akan memiliki tingkat motivasi belajar yang baik, sehingga akan berpengaruh terhadap porestasi belajarnya.

Penelitian ini mengkaji mengenai pengaruh efikasi diri, kecerdasan emosional, dan motivasi belajar terhadap prestasi belajar matematika siswa. Peneliti selanjutnya dapat menggunakan penelitian ini sebagai sumber data dan bahan perbandingan dalam melakukan penelitian 
relevan. Seperti, melihat pengaruh model pembelajaran terhadap hasil belajar dengan memperhatikan efikasi diri, kecerdasan emosional dan motivasi belajar.

\section{DAFTAR PUSTAKA}

Alfiah.G, Opod.H \&Sinolungan. J. S.V. (2013). Gambaran Kecerdasan Emosional Dan Prestasi Belajar Pada Siswa Negeri XI Manado. E-Biomedik,1(1).64-70.

Bandura, A (1994). Self-Efficacy. Encyclopedia of human behavior, 4.71-81.

Cleopatra. (2015). Pengaruh gaya hidup, dan motivasi belajar terhadap prestasi belajar matematika. Jurnal Formatif, 5(2).168-181.

Gusniawati.M. (2015). Pengaruh Kecerdasan Emosional Dan Minat Belajar Terhadap Penguasaan Konsep Matematika Siswa SMAN Di Kecamatan Kebon Jeruk. Jurnal Formatif,5(1).26-41.

Haling, A. (2007). Belajar dan Pembelajaran. Makassar: Badan Penerbit UNM.

Hidayat, A. (2016). Pengaruh Problem Based Learning dengan Pendekatan Problem Solving dan Self Efficacy terhadap Hasil Belajar Matematika Siswa SMP Negeri 1 Rumbio Jaya. Journal Cendekia, 1(2). 01-10.

Jamil, M. (2015). Pengaruh kemampuan Numerik, kecerdasan emosional dan menghafal Alquran terhadap prestasi belajar matematika siswa. Pasca Sarjana UNM, Makassar.

Muklis.Y.M \& Sanhadi, K.C.D. (2016). Kontribusi Self-Efficacy Dan Kemampuan Komunikasi Matematis Terhadap Prestasi Belajar Matematika Siswa. Prosiding Konferensi Nasional Penelitian Matematika dan Pembelajarannya (412-419). Surakarta, Indoneseia :Universitas Muhammadiyah Surakarta

Mulyaningsih, I.E (2014). Pengaruh interaksi social keluarga, motivasi belajar, dan kemandirian belajar trehadap prestasi belajar. Jurnal Pendidikan dan Kebudayaan,20(4).441-451.

Rustika.I.M .(2012). Efikasi Diri: Tinjauan Teori Albert Bandura. Buletin Psikologi,20(1-2).1825.

Styawan.A.A. \& Simbolon. D. (2018). Pengaruh Kecerdasan Emosional Terhadap Hasil Belajar Matematika Siswa SMK Kansai Pekanbaru. PPM,11(1).11-18. 